\title{
Neo-sentimentalism of L.S. Petrushevskaya in the Light of Catharsis Through Laughter and Tears
}

\author{
Alexander V. Kubasov* \\ Ural State Pedagogical University \\ 26 Kosmonavtov, Yekaterinburg, 620017, Russia
}

Received 22.03.2017, received in revised form 22.01.2018, accepted 05.02.2018

The present article is dedicated to the problem of Neo-Sentimentalism, one of modern art discourses, represented by Lyudmila Petrushevskaya. The paper presents the allied notions of sentimentality, sentimentalism and neo-sentimentalism. The first refers to a personal quality, the second is a literary school, while the latter is a discourse with its roots going back to the first and the second. The distinctive feature of neo-sentimentalism is its synthetic character, the way it combines the uncombinable. Thus, it makes sense to study the works of Petrushevskaya in the light of catharsis through laughter and tears. One of the pioneers in combining such dissimilar discourses is Gogol. The combination of laughter and tears is brightly manifested itself in "The Overcoat" short story. Russian literary criticism classified this story as sentimental naturalism. However, the movie script by Petrushevskaya, based on the story by Gogol, belongs to neo-sentimentalism, since it presents the tearful component against the background of laughter. It is worth noticing how the writer combines anecdote and parable associated with two different catharses, in one script. The second text that served as a basis for the current research is "The Bohemia" story. It is ultimately concise: it consists of ten phrases only. It presents other forms of combining laughter and tears, determined by brevity. First of all, it is an intertextual reference to a music piece (Puccini's "La Bohème" and a famous Soviet song) and to a Rembrandt painting. Secondly, it is an unusual form of narration, volatile between the figures of an uncertain storyteller and an impersonal narrator. Due to this form, in some cases the tearful aspect comes to the fore, and in the others the element of laughter is driven through.

Keywords: neo-sentimentalism, discourse, catharsis through tears and laughter, intertext, L.S. Petrushevskaya.

Research area: philology.

Citation: Kubasov, A.V. (2018). Neo-sentimentalism of L.S. Petrushevskaya in the Light of Catharsis Through Laughter and Tears. J. Sib. Fed. Univ. Humanit. soc. sci., 11(9), 14121424. DOI: 10.17516/1997-1370-0177.

(C) Siberian Federal University. All rights reserved

* Corresponding author E-mail address: kubas2002@mail.ru

This work is licensed under a Creative Commons Attribution-NonCommercial 4.0 International License (CC BY-NC 4.0) 


\section{Theoretic base}

"Often, through laughter, visible for the world, one drops tears, invisible for the world". This quote from Gogol's "Dead Souls" has almost become a cliché, deeply embedded in the corpus of Russian proverbs. For us, it indicates the sequence of layers: laughter as the external, visible one, and tears as the invisible one. But can we invert these positions to find tears in the foreground and laughter behind? Can laughter hidden from the world, be heard through the tears, visible for the world? How much adjustment for laughter can tears allow? What does such a mix contribute to a piece of literature? Answers to these questions can only be found through the analysis of certain texts.

The definition of "catharsis" has a long history, going back to Aristotle. Without looking deep into it, let us turn to the definition formulated by L.S. Vygotsky. In "The Psychology of Art" he briefly outlines various approaches to the notion and writes that "there is no other term in psychology which so completely expresses the central fact of aesthetic reaction, according to which painful and unpleasant affects are discharged and transformed into their opposites. Aesthetic reaction as such is nothing but catharsis, that is, a complex transformation of feelings" (Vygotsky, 1987: 204). Relying on the opinion of Vygotsky, we may claim that the aesthetic reaction when tears break through laughter or, on the opposite, laughter turns into tears, is the catharsis, known for its transitional character, manifested in the "aesthetic reaction law". According to Vygotsky, this reaction "comprises an affect that develops in two opposite directions but reaches annihilation at its point of termination" (Vygotsky, 1987: 204).

The peculiarity of the cathartic reaction reflected in modern literature is its reduced character and qualitative non-uniformity, i.e. tears and laughter do not appear in their pure form. They are replaced with their derivatives: open laughter is substituted by irony, black humour, a sarcastic grin, while tears are replaced with the feeling of bitterness, regret, sympathy, tenderness.

The next remark concerns the problem of correspondence and difference between the definitions of sentimentalism, neo-sentimentalism, and sentimentality. Obviously, sentimentality is recognized as an eternal human quality, which manifests itself in reality at certain times getting simultaneously activated in literature. It appears like sentimentality may be associated with the problem of gender: no matter what, women are more likely to perceive the world with tears than men. If sentimentalism as a literary school refers to a certain period of time $\left(18^{\text {th }}\right.$ - early $19^{\text {th }}$ centuries), neo-sentimentalism should be interpreted, first of all, as a discourse embodied in the genres and styles of texts. It is a phenomenon that "emerges" from time to time, depending not only on 
the problems of time, but also on the personal qualities of the artist and the object he depicts.

Neo-sentimentalism and sentimentalism may be also described as a donor-school and a recipient, which is the modern discourse, existing on its basis. Just like other literary schools, sentimentalism is synthetic in its own way. So is neo-sentimentalism, but in an emphasized, radical way. It had to inherit something from its donor and, consequently, to resemble it in anything, retaining, on the other hand, its own distinctive features.

\section{Neo-sentimental discourse practices and their implementation in the prose by Petrushevskaya}

One of the brightest representatives of modern neo-sentimentalism is Lyudmila Petrushevskaya. Researchers emphasize the symbiotic character of her artistic world. According to T.G. Prokhorova it "is a complicated and volatile phenomenon. It is a web of realistic, post-modern, sentimentalist, baroque, romanticist, naturalist, modernist intentions; some of them may be dominant in one book, while in another some other comes to the fore" (Prokhorova, 2008: 4). Let us add that in some cases the "sentimentalist intentions" of Petrushevskaya act as the main background, while in the others they serve as a substrate, as a ground hardly visible through everything that "grows" on it.

Perhaps, some works of Petrushevskaya grew from "The Overcoat" by Gogol; but it is not Gogol's original $19^{\text {th }}$ century text, but the life of this piece in the "big time", in the $20^{\text {th }}$ century, when, remaining textually unchanged, it changed the emphases, deepened some meanings and pushed other ones to the background. Petrushevskaya grew from "The Overcoat" that comprises the experience of forthcoming literature, the experience of its later reading and interpretation.

It is commonly known that Lyudmila Stefanovna is the author of the script for the animation based on "The Overcoat", which is still in progress at the studio of director Yuri Norstein. The script notes for the animation are the material where the inverse laughter-and-tears combination is implemented.

The writing strategy of Petrushevskaya is isomorphic to that of "The Overcoat". Let us analyse a small fragment of text: "So easily and lightly, with jokes and proverbs, with playful turns and winks, the writer suddenly stabs the reader covertly, slyly, right into his heart..." (Petrushevskaya, 2003: 233). Here comes the question: who wrote it, and who is it about? Did a sagacious critic write it about Petrushevskaya, or did Petrushevskaya 
write it about Gogol? Both answers are possible. In fact, Petrushevskaya wrote it about Gogol. Tellingly enough, the script author reads the original story through the prism of laughter and tears, driving the laughter of Gogol, his "playful turns and winks" to the fore, and pushing tears and the "stab" to the background. If the writing strategies of the writers are isomorphic, their techniques are doubtlessly different, due to the idiomatic and stylistic differences. "For Petrushevskaya, the paradox of word and phrase, turns of the story and psychological motives are the most natural, organic form of depiction and perception, adequate to the life dynamics as such. All her stories describe a person getting lost in life, a person the world cannot accommodate. This idea manifests itself in the antinomy, the "reverse" poetics, beyond which the world created by this author cannot be imagined" (Markova, 2013: 90). The variants of the invariant story of "a person getting lost in life, a person the world cannot accommodate" pushing it out of itself, can be easily found in the prose by Gogol. First of all, we refer to such characters as artist Piskarev, Poprischin, and, of course, Akaky Akakievich.

Let us return to the strong position of the text, to the first phrase of the script where the name and last name of Akaky Akakievich Bashmachkin are announced. The character and even the destiny of this person are concentrated in the name. Gogol has thoroughly worked it through, selecting it from several options. The associative potential of the name, once interpreted as "stuttering" (Shklovsky, 1970: 19), is pushed to the fore and articulated by the script writer. This name is perceived as something obscene, raising a slightly camouflaged reference to the bodily bottom. It determines the carnival atmosphere of the story, where the impossible turns possible, where everything is shifted, where the border between the physical and metaphysical worlds is sometimes absolutely invisible.

Unlike the first name, the last name of the character sounds pretty decent, while its semantics contains a sort of shift as well. Bashmakov last name sounds more common to a Russian ear. Bashmachkin is not a derivate of the word bashmak; it originates from bashmachok (bashmak with a diminutive suffix). In his classic article "How "The Overcoat" by Gogol is made", B.M. Eihenbaum noticed that the choice of the last name "may be explained with the author's inclination to diminutive suffixes, typical for his style, or a greater articulatory expressiveness (power of mimic and pronunciation) of the form, that makes a sort of a sound gesture" (Eihenbaum, 1969: 312). The diminutive character of Gogol's stylistic manner may also be associated with the development of a certain character type, along with the problem of sentimental naturalism (Vinogradov, 1976). The motive of a "little man" once opened by Pushkin A.S. was appropriately 
continued in the Petersburg story by Gogol. Still appealing to obvious associations of the readers, Gogol encompasses not just the centre, but also the periphery of the readers' expectations. The category of shift turns to be the underlying one. Bashmachkin last name still has a distinctive seme of the bottom, but not the bodily, but social bottom: "the very bottom of the humankind". Therefore, the primary conflict is embedded in the nomination of the main character.

The laughter and tearful reactions of the reader are manifested from the very beginning of the script: "What can be funnier than a mother, that old deceased woman, having a baby born in a uniform and with a bold head. When baptized, the baby cried, wincing as though he had predicted that he would become a titular counsellor" (Petrushevskaya, 2003: 231). It is easy to imagine this absurd and fantastic story as a cartoon. The fragment is based on the oxymoron correlation of different images and readers' reactions. The cartoon artist faces the challenge of depicting a character who looks like a public officer of adult age, wearing "a uniform and with a bold head", and a crying child at the same time. Let us remind you the words of Vygotsky: Petrushevskaya programmes the "affect developing in two opposite directions".

The script writer finds the sorest point and writes "what the movie is about": "And when he was entering his department, the gatemen did not just remain sitting, they did not even look at him, as though a simple fly was flying across the chamber". What can be smaller than a fly? But it is the time for us to slow down and speak of mercy". Mercy is something that has always mattered, something the world literature has always written about. Mercy is the ethical core of sentimentalism. It is not a coincidence that the author recalls such names as Karamzin, Pushkin, Dickens, Andersen. Here the author points at the main type of catharsis in sentimental literature, that is, tears: "As it was impossible to save the weak and the defenceless, the writer felt guilty, and so did the reader, following him. The reader shed the tears of pity and sympathy" (Petrushevskaya, 2003: 233). In sentimental literature an open, homogenous, non-reduced reaction was still possible, and the reader "shed some tears". In neo-sentimentalism, the purity of the reader's reaction is always broken due to other emotions that combine with it. In her notes to the script, Petrushevskaya explicitly points at the secondary, non-literature source, that is supposed to become one of the proto-genres for Norstein's cartoon. It is an old silent German comedy, where the main character is also a "little man". The character played by Charlie Chaplin is, to some extent, an American successor of Akaky Akakievich from Russian literature. In the script, it is formulated as follows: "It is expected to be made in the spirit of old comedies, where the laugh, the Homeric laugh of the 
audience breaks out when a creamy cake is smashed against a lady's face, or when a fat man sits on a chair, while the chair is... What a hoot!" (Petrushevskaya, 2003: 235). Here the second, "pure" non-reduced reaction of the audience, the "Homeric laugh", is presented. It can be hardly caused by Gogol's "Overcoat". But their correlation in the artistic space of the cartoon is the thing that creates the cathartic "affect developing in two opposite directions".

For Gogol, the important element of a story was the existential conflict between the man and the conditions of his existence, between the little man and the nature of state authorities on one hand and the natural power of society on the other. One of the modern problems is the triumph of the mass, the colleagues of Akaky Akakievich and other surrounding people. Obviously, the problem of the reader/viewer's selfidentification is connected not to the main character, but with incidental characters. The viewer is brought to realize that there are lots of modern Akaky Akakieviches who, as Dostoyevsky said, "run around all the time, but in a sort of some liquefied condition", unnoticed. According to Petrushevskaya, this movie needs to speak of the daily dictatorship of the crowd, suppressing individuality not with any malicious actions, but with its indifference, disregard, similar to that of the state authority. Just like in the story by Gogol, in the movie the latter is embodied by the Prominent Personage. It is presented as Nietzsche's Übermensch, a god on earth, indifferent to an ordinary man. The idol-likeness of the Personage is expressed through the fact that it does not produce any laugh or tears, and for this reason the outreach of Akaky Akakievich was doomed to failure from the very beginning. Petrushevskaya makes it clear: "In "The Overcoat", Gogol picked the sorest situation of the modern world and described a person, perfect in complete defencelessness: not a fool, not an ill person, just a defenceless one. And described this variant of life from the beginning to the end. To the limit where nothing and no one helps, when the person tries to manage with his own weak efforts and finally dies" (Petrushevskaya, 2003: 233-234).

The epilogue of the script is associated with establishing the true scale of personalities in the historical prospective: the diminution of one and hyperbolization of another. The Prominent Personage turns "so small. And Akaky Akakievich, on the opposite, becomes so big, so enormous, over the city $<\ldots>$. The enormous Akaky Akakievich and the whole Petersburg, the whole world standing on him..." (Petrushevskaya, 2003: 245).

Let us investigate the interference of the catharsis of tears and laughter on another example. It is "The Bohemia", which contains only ten phrases given by the author as a united textual flow without division into paragraphs. 
In Petrushevskaya's works, the most important principle allowing to show the symbiosis of laughing and tearful beginnings, is the principle of intertextuality. It is declared from the very beginning of the story, through the mention of Puccini's opera "La Boheme". Intertextuality makes it possible to expand the presupposition of the reader at the expense of bracketing the known, the implied out of the narration. The narrator initially appeals to the mass cultural consciousness, for which the primary meaning of the word "bohemia" is associated with Puccini's opera. In the consciousness of ordinary cultural man, the opera "La Boheme" takes place in the circle of typical "unhappy love" stories. However, the details of the opera to clarify the meaning of the story are not necessary, for this inevitably leads the reader beyond the averageness. What is important is the long-varying outline in the art of history about the fact that "someone loved someone, lived, then he or she broke up with their lovers or were abandoned themselves". Thus, the archetypal invariant of the plot is initially set, the next realization of which will be the story of Klava, and the reader's expectations are initially associated with this. However, in the same first sentence, this assumption is rejected. It is said about 'Bohemian Klavdia' that she had "no romance with no one". The reader's internal question, then "what is the story about", remains without an answer for a while. Therefore, from the first phrase the intrigue is fastened.

Allusions of Petrushevskaya are not simply referred to some literary, musical or pictorial realities. They create a certain tonality of the story. Some part of the first phrase is devoted to the "bare" dirty feet of the main character: "... in the summer, Klavdia's feet plunged decent people into embarrassment, but such should be the bare feet of a young woman walking along the streets and such should be her legs, face and hair, and so silent, without claims, should be the bohemia" (Petrushevskaya, 1996: 38). The visual image sends the reader to the famous painting by Rembrandt from the Hermitage, "The Return of the Prodigal Son". Thus, the second standard plot is set, though not melodramatic, connected with "La Boheme", but a parable, through a picturesque canvas referring to the text of the Bible. Pseudological persuasiveness ("such should be her legs, face and hair, and so silent, without claims, was supposed to be bohemia") is one of the forms of creating an ironic modality, which is amplified by the fact that it itself represents a variation of the well-known phrase from "Uncle Vanya" by Chekhov, which became an aphorism: "Everything should be first-rate in a man: his face, clothes, soul and thoughts". The author of "The Bohemia" seems to bring a crooked mirror from the room of laughter to the known artefacts and with its help creates a semantic perspective. 
Petrushevskaya is an expert in connecting the symbolism of the parable with the meaningfulness of the anecdote. The ambivalence of the cathartic reaction is due to the fact that the structural components of these two heterogeneous genres are involved in this story. The main vector of the genre movement in the story is from the anecdote to the parable. Anecdotal oxymorism gradually recedes before the parable's symbolism. It is significant that Klavdia's unborn child was a boy. The combination of this fact with the implied characteristic of Klavdia as a holy fool adds to the image of the main character a barely perceptible shade of the Holy Mother image given not in the canonical theological form, but again with a "shift" in the artistic image. In the story, the sacred plot of the Immaculate Conception is profaned: after all, Klavdia had "no romance with no one". Therefore, one more genre grows out from the interaction of the anecdote and the parable, the apocrypha.

The parable and the anecdote, despite all their obvious difference, have a similar nominative presentation of the main character, which in these genres is only called or denoted by some feature, but is not characterized. V.I. Tyupa, quoting S.S. Averintsev on the features of the main characters of the parable who "appear before us not as objects of artistic observation but as subjects of ethical choice" (Averintsev, 1971: 21), further notes the fundamental difference between the main character of the anecdote: "The main character of the anecdote, on the contrary, is precisely the object of aesthetic (laughter) observation" (Tyupa, 1989: 20). The protagonist of Petrushevskaya's story, belonging to two genres, two coordinate systems and two worlds, is portrayed in two ways: in some cases it gravitates toward anecdotal object types, in others to the parable's "subjects of ethical choice". "Bohemian Klavdia" is an anecdotal characteristic, but the failed mother grieving for her unborn child, is the character of the parable.

The beginning of the text abounds with indefinite pronouns and adverbs ("someone, something, somehow"). Uncertainty is strengthened with the help of other linguistic means ("she wrote either poetry, or novels", "they either collected songs, or sang themselves at weddings"). The category of uncertainty is important not only for the image of Klavdia, which oscillates between anecdotal and parabolic poles. Uncertainty is also typical for the narrator who plays the key role in the work, especially if we take into account that in the text there is not a single replica of the heroes in the form of direct speech, only at the end there are two cases of indirect speech, of Klavdia and her mother. Uncertainty gives the narrator the feature of "insecurity". But this "insecurity" is not constant throughout the narration. In the middle of the story it weakens, the speech of the "unreliable" narrator imperceptibly passes into the form of 
an impersonal narration, into a voice that is already devoid of doubts connected with ignorance. However, at the end of the story, the uncertainty that has disappeared for a while appears again. But now it is functionally and meaningfully different. It becomes imaginary, because the reader should already have formed his own idea of the main character and her fate. Therefore, the words that "everyone took her calculations and stories with a strange feeling" actually act as a euphemism for the reader, who has determined their feelings in the inner speech.

Uncertainty is deeply meaningful in relation to the narrator. Who leads the narration? Whose voice is this? An impersonal narrator? But he does not possess the property of omniscience. A storyteller? But we do not observe the most important identifier and marker of it, the pronoun 'I'. With the help of the principles of uncertainty and transitivity, Petrushevskaya creates a hybrid, intermediate version that allows to use the narrative capabilities of both forms, and most importantly - to combine different types of intonations, to vary the heterogeneous modality, thus creating the "bulkiness" effect of the minimalist text. At the beginning of "The Bohemia" the narrator is close to the figure of a storyteller, who can be defined as a person from a 'choir', who has partially heard something somewhere, about something that he knows little but is not completely sure about the information reported to him. A 'choral narrator' (let us call so this form of narration) conveys not so much his opinion and his vision, as the opinion of the majority, the crowd, the masses. The "choir" at the end of the story will transform into a real image: "But everyone took her calculations and stories with a strange feeling, and all were silent in return ..." (Petrushevskaya, 1996: 40). Petrushevskaya creates an ambivalent anecdotic-parabolic image of a silent 'choir', neither talking nor singing.

The transition from the 'I' form to an impersonal narration would be difficult to make within a couple of phrases. Uncertainty gives the author the necessary degree of freedom, secretly motivates to abandon unnecessary details, and most importantly, makes the transitions from one form of narration to another invisible. The fluctuations within the range, outside the poles, allow to achieve this effect. At the same time, the absence of paragraphs in the text creates the impression of a single speech flow, the change in the nature of the narration is mixed. The illusion of a passionate story about the protagonist is born. An inconspicuous shift throughout the story to an impersonal narration leads to a change in the length of phrases as well. They are markedly reduced. The hysterical, chaotic speech of the storyteller is replaced by the verified style of the impersonal narrator. 
It is important for Petrushevskaya to make the reader dwell on certain details. For this purpose she uses the methods of retardation and reader's frustrated expectations. One of the means providing a retarding effect is the dephraseologization of known idioms. The idiomatic expression existing in the minds of native speakers as a kind of stable integrity, is automatically recognized and read in its unity. Usually the reader 'skips' through phraseological units without paying attention to them. Petrushevskaya breaks readers' expectations. It I difficult to 'skip' an idiom in this text, because contrary to the tradition, it is given with a modified component composition. This, for example, is the idiom 'three times a day' usually in schedules or characterizing the usual frequency of eating meals. It is said that Klavdia "ate three days a week". With such a diet, a person must inevitably wobble from hunger (which is 'shatatsya' in Russian). Petrushevskaya accurately predicts the expected reader's reaction. However, instead of the expected continuation, the reader is prepared to malfunction: the word 'shatatsya' appears after the transformed game idiom in the meaning of 'wandering', reinforcing its ironic tone: "she ate three days a week and was only wandering from house to house with a company of the same kind as scoundrels" (Petrushevskaya, 1996: 39). Dephraseologization is one of the favourite techniques used in the genre of anecdote.

Retardation works to create an illusion of the temporal extension of the narration. The reader should pause over the line, understand the meaning of the details, hidden symbolic details. In "Karamzin", Petrushevskaya creates a paradoxical oxymoron transformation of a famous idiom, which can be regarded as an artistic declaration of the writer: "I give details/life is detailed/delay is similar to life". Retardation is achieved through the reification, objectification of the figurative meaning of the word that is part of the idiom. In its origins, this method goes back to the tradition of Gogol, who developed and deployed abstraction or alogism to such an extent that they took the form of reality.

The effect of frustrated expectations is achieved by turning over and "deviating" the usual phenomena. Thus, it is said about "Bohemian Klavdia" during her wanderings through the northern villages that she "confronted an absolutely incomprehensible matter: she had got a terrible stomachache". The fragment allocated due to "deviation", as a rule, is important either in the plot or in the concealed symbolic plans. Later, the meaning of "incomprehensible" pain in the stomach will be revealed. When the reader understands that it was a symptom of the main character's pregnancy, they should recall the place where this was first mentioned. Thus, by rethinking the already wellknown, returning to the already read, but initially given without explanation in the story, a system of internal ties is created. 
One of Petrushevskaya's works obviously gravitating toward neo-sentimentalism, is the already quoted "Karamzin. The Village Diary". Its title is based on the principle of metonymy. After all, one of the most famous works of Nikolay Mikhailovich is "The History of the Russian State". Thus, the "village diary" is given the features of an all-Russian scale chronicle. In the story "The Bohemia" the function of symbolic expansion of space is performed by a reminiscence expression "birch and rowan", which seems quite simple. The story is ringed with two musical images: in the beginning it is the opera by G. Puccini. The final makes one remember another work. At the end of the story it is said that Klavdia's mother, "having spent a lot of money, for some reason moved the lavatory to a new place, and planted a rowan and a birch at the place where the old one was". The last words act as an associative challenge in the mind of the reader of the most famous Soviet-era song "Our Land" (music by D. Kabalevsky, lyrics by A. Prishelts), which in the context of the story, like Gogol's "The Overcoat", is reinterpreted and, in a captured form, realizes two aesthetic reactions - tearful and laughing:

\section{То березка, то рябина,}

Куст ракиты над рекой.

Край родной, навек любимый,

Где найдешь еще такой!

\section{[A birch, a rowan,}

A goat willow above the river.

Our native land, loved forever,

Where else will we find such!]

Sergei Bocharov rightly wrote: “The sensitive sentimental basis of Petrushevskaya's hard prose always was in the subsoil of this prose and burst out in lyrical splashes ..." (Bocharov, 1999: 559). Sentimental sensitivity would be cathartically less effective and aesthetically more univocal if the sentimental tearful tone was not combined with the laughable derivatives, if the sad beginning did not have a comic underside.

\section{References}

Averintsev, S.S. (1971). Pritcha [Parable]. In Kratkaia literaturnaia enciklopediia [Brief Literary Encyclopedia], (6). Moscow, Sovetskaia Rossiia, 20-21. 
Vygotsky, L.S. (1987). Psikhologiia iskusstva [Psychology of art]. Moscow, Pedagogika, 345 p.

Bocharov, S.G. (1999). Siuzhety russkoi literatury [Topics of Russian literature]. Moscow, Iazyki russkoi kultury, 632 p.

Vinogradov, V.V. (1976). Shkola sentimental'nogo naturalizma (Roman Dostoevskogo "Bednye liudi" na fone literaturnoi evoliutsii 40-kh godov) [School of the sentimental naturalism (Dostoevsky's novel "Poor Folk" on the background of literary evolution of 40s)]. In Poetika russkoi literatury [Poetics of Russian Literature]. Moscow, Nauka, 141-190.

Markova, T.N. (2013). Fiziologiia i metafizika semeinoi zhizni v rasskazakh L. Petrushevskoi [Philosophy and Metaphysics of family life in the stories of L. Petrushevskaya]. In Ural'skii filologicheskii vestnik. Russkaia literatura XX-XXI vekov: techeniia i napravleniia [Ural Philology Gazette. Russian literature of the $20^{\text {th }}$ $21^{\text {st }}$ centuries: trends and directions]. Ekaterinburg, 2013, 88-98.

Petrushevskaya, L.S. (2003). Stsenarnye zametki k mul'tfil'mu "Shinel"” [Script notes for the animated film "The Overcoat"]. In Deviatyj tom [The ninth volume]. Moscow, EKSMO, 333.

Petrushevskaya, L.S. (1996). Bogema [The Bohemia]. In sobranie sochinenii [Collected works], (2). Kharkiv, Moscow, TKO AST, 367.

Prokhorova, T.G. (2008). Proza L.S. Petrushevskoi kak sistema diskursov [Prose L.S. Petrushevskaya as a system of discourses]. Dissertation for the Degree of the Doctor of Philological Sciences. Kazan, 338

Tyupa, V.I. (1989). Khudozhestvennost' chekhovskogo rasskaza [Artistry of Chekhov's story]. Moscow, Vysshaia shkola, 135 p.

Shklovsky, V.B. (1970). Tetiva. O neskhodstve skhodnogo [Bowstring. On a similar dissimilarity]. Moscow, Sovetskii pisatel', 375 p.

Eihenbaum, B.M. (1969). O proze. [On the prose]. Leningrad, Khudozhestvennaia literatura, $504 \mathrm{p}$. 


\title{
Неосентиментализм Л.С. Петрушевской \\ сквозь призму слезного и смехового катарсисов
}

\author{
A.В. Кубасов \\ Уральский государственный педагогический университет \\ Россия, 620017, Екатеринбург, пр. Космонавтов, 26
}

Статья посвящена проблеме неосентиментализма, одного из современных художественных дискурсов, ярким представителем которого является Людмила Петрушевская. В работе разводятся смежные понятия сентиментальности, сентиментализма и неосентиментализма. Первое рассматривается как личностное качество, второе - как литературное направление, а третье - как дискурс, корнями связанньй с первым и вторым понятиями. Отличительной чертой неосентиментализма признается его синтетичность, соединение, казалось бы, несоединимого. Поэтому логично, что творчество Петрушевской рассматривается сквозь призму двух типов катарсиса: слезного и смехового. Одним из литературных первооткрывателей такого соединения разнородных дискурсов является Гоголь. Соединение смеха и слез очевидно проявилось в его повести «Шинель». Это произведение отечественное литературоведение относило к сентиментальному натурализму. Киносиенарий по повести Гоголя, написанный Петрушевской, - произведение неосентиментализма, так как в нем слезное начало подается на смеховом фоне. Важно и то, что писательница соединяет в сценарии два разнородных жанра: анекдот и притчу, которые тоже связаны с разнородными катарсисами. Вторым художественным текстом для исследования поставленной проблемы выбран рассказ «Богема». Он предельно лапидарен: состоит из десяти фраз. В нем представлены другие формы соединения смеха и слез, обусловленные краткостью. Во-первых, это интертекстуальные связи, отсылаюшие читателя кмузыкальным произведениям (опера Пуччини «Богема» и известная советская песня), к известной картине Рембрандта. Во-вторых, это необычная форма повествования, которая колеблется между фигурой ненадежного рассказчика и безличным повествователем. Эта форма позволяет в одних случаях актуализировать слезное начало, а в других-смеховое.

Ключевые слова: неосентиментализм, дискурс, слезный и смеховой катарсисы, интертекст, Л.С. Петрушевская.

Научная спещиальность: 10.00.00 - филологические науки. 